\author{
Michał Marcin KOBIERECKI \\ University of Lodz, Poland
}

\title{
Canada - USSR Hockey Exchanges. Between Positive and Negative Sports Diplomacy ${ }^{*}$
}

\author{
Kontakty hokejowe Kanada - ZSRR. \\ Pomiędzy pozytywną a negatywną dyplomacją sportową
}

\section{- Abstrakt •}

Celem artykułu jest zbadanie dyplomacji hokejowej pomiędzy Kanadą a Związkiem Radzieckim, do jakiej doszło w latach siedemdziesiątych XX wieku. Obejmowała ona organizacje szeregu meczów w hokeju na lodzie, których bezpośrednim celem było nawiązanie bliższych relacji pomiędzy dwoma należącymi do przeciwstawnych bloków geopolitycznych krajami.

W artykule podjęta została próba weryfikacji szeregu hipotez badawczych. Główna zakła$\mathrm{da}$, iż dyplomacja hokejowa była w rzeczywistości połączeniem elementów pozytywnej i negatywnej dyplomacji sportowej. Zgodnie z kolejną, kontakty hokejowe były zarazem przejawem i narzędziem zbliżenia pomiędzy krajami, natomiast według ostatniej hipotezy wybór hokeja na lodzie jako narzędzia dyplomatycznego był adekwatny.

Słowa kluczowe: Dyplomacja hokejowa, dyplomacja sportowa, upolitycznienie sportu, stosunki Kanada-ZSRR

\section{- Abstract •}

The aim of the article is to investigate the issue of hockey diplomacy between Canada and the Soviet Union, which was held in 1970s. It encompassed a series of exhibition matches in ice hockey, which were directly aimed to improve relations between the two states belonging to different Cold War alliances.

In the article an attempt to verify a number of hypotheses was made. According to the main one, the hockey exchanges were in fact a fusion of positive and negative sports diplomacy. The second hypothesis states that hockey diplomacy was at the same time an effect and a tool of Canadian and Soviet desire to better their bilateral relations, while according to the last one, selection of ice hockey was adequate concerning the diplomatic objective of political rapprochement.

Keywords: Hockey diplomacy, sports diplomacy, politicisation of sport, Canada-USSR relations

* Funding: The research has been financed by National Science Centre, Poland, within project number 2015/19/D/HS5/00513. 


\section{Introduction}

The aim of the article is to investigate the issue of hockey diplomacy between Canada and the Soviet Union, which is an example of positive sports diplomacy directed at fostering positive objectives of states, for example rapprochement between hostile countries. The issue had received a fair interest among researchers worldwide, probably because of the great attention and symbolic meaning it gained in Canada, but in Poland it remained neglected in terms of scientific research. However, concerning its significance and influence on the evolution of this kind of sports diplomacy, it is worth to be undertaken as a research problem.

Sports diplomacy is defined in various ways, more narrowly or encompassing a vaster sort of diplomatic utilization of sport. The term is usually referred to concerning its role in shaping international image of a state and in fostering foreign policy goals. Those objectives may be either positive - directed at international cooperation and political rapprochement, or negative - directed at using sport for the sake of conflict and escalation of international tensions (Rowe, 2011; Saxena, 2011; Potter, 2009). Accordingly, sports diplomacy is sometimes described as either positive or negative. In the context of the use of sport in Canada - Soviet Union relations, generally sport has been employed as a tool of positive sports diplomacy, however according to one of the hypotheses, it actually included elements of negative sports diplomacy as well.

Sports diplomacy is generally considered as an element of a broader term public diplomacy (Ociepka, 2013), which is defined as the communication of the policy of international actor to the people of another country (Pamment, 2013). Although in general the political elites also belong to the aims of public diplomacy, societies seem to remain as the main subject. This was a matter of Canada - USSR hockey diplomacy as well.

Hockey diplomacy between Canada and the Soviet Union is an example of positive sports diplomacy directed at international rapprochement. It must be noted though that ice hockey had been used for diplomatic sake by other countries as well, for instance in relations between the USA and the USSR. Nevertheless, it appears that Canadian - Soviet hockey exchanges were the most sophisticated and to greatest extent affected their bilateral relations. For this reason hockey diplomacy as a term is usually associated with relations between those two countries and this will be the object of the investigation.

In the research, an attempt to verify a number of research hypotheses will be made. According to the main assumption, the Canada - USSR hockey diplomacy was in fact a fusion of positive and negative sports diplomacy, even though the 
positive aspects appeared to be dominating, particularly in the first period. The positive motivations encompassed most of all political rapprochement and enhancing the societies' perception in the second nation, while the negative aspects might be associated with the desire to gain international prestige by winning in the exhibition matches, obviously on the expense of the other participant. The second hypothesis states that the hockey exchange was at the same time an effect and a tool of Canada's and Soviet Union's desire to better their bilateral relations. Accordingly, hockey diplomacy was needed to bring the two states closer, but at the same time it was only possible after the political will for the detente appeared at both sides. Finally, the research is aimed to find out whether the selection of ice hockey was adequate concerning the positive diplomatic objectives of the sports contacts - it was, according to the final hypothesis. As a matter of fact, sports diplomacy directed at political rapprochement between unfriendly states is usually very fragile and any controversies that may appear in respect to the exchange may sometimes derail the whole diplomatic progress. This suggests picking minor sports for this sake, but at the same time such sports do not draw attention of the societies, which are the main objects of sports diplomacy.

The research is an empirical case study concerning one of the examples of sports diplomacy, generally aimed at improving the state of relations between the Soviet Union and Canada, two states belonging to opposing geopolitical blocks of states, with the use of athletic exchanges in ice hockey. The data was acquired with the use of existing, most of all historical elaborations on Canada - Soviet hockey exchanges by foreign authors and archives of media coverage. The acquired data were then analyzed with the use of decision-making method - in order to determine process of establishing sport exchange and the motivation of policy-makers, and hermeneutics - concerning the need to interpret the events and speeches of the engaged people from the perspective of positive or negative diplomatic and political meaning. The results of the research, apart from verifying the hypotheses, will help in searching for general regularities about sports diplomacy, contrary to most of the existing researches that tend to consider the issue individually.

\section{Circumstances of Establishing Hockey Diplomacy}

Ice hockey as a sport is very important in Canada, which as a matter of fact for many years had been dominating in international competitions. Some authors even suggest that this particular sport has contributed to the evolution of Canadian national identity, considering lack of common culture and language. Un- 
der such circumstances, ice hockey might have been one of the very few factors uniting French and English speaking Canadians (Soares, 2007). Canada is also globally associated with this sport. As Evan Potter (2008) has noted, ice hockey has its role in defining international image of Canada - "northern, rugged, and determined" (p. 122). Despite all this, the results that Canadian national team was achieving in international competitions began to deteriorate in 1950s and 1960s. It can be associated with better performance of communist states in this sport, especially the Soviet Union and Czechoslovakia. One of reason for this was that the best Canadian hockey players competed in professional league NHL, thus becoming professionals with no right to compete in prestigious international amateur competitions such as the Olympic Games or world championships. Meanwhile, in the communist states, sport was officially amateur only, although actually the best athletes were fictionally employed and could spend all their time on sport (Godlewski, 2009).

At this time, policy-makers in Canada became aware of the prestige damage resulting from the weak performance of the national team of Canada in ice hockey at the Olympics, world championships, and other tournaments organized in Europe (Macintosh, Hawes, 1994). At the end of 1960s and the beginning of 1970s Canadians event suggested allowing professionals to participate in world championships. As a result of refusal by International Ice Hockey Federation (IIHF), Canada withdrew from the federation and the same time resigning from hosting world championships in 1970 (Macintosh, Hawes, 1994; Soares, 2008). Even before the mentioned withdrawal from international ice hockey competition, Canadian diplomats began to strive for organizing hockey exchanges between professional players from Canada and Soviet national team. At that time those strives were unsuccessful though (Fulbright Canada). Those events were very important concerning the future hockey diplomacy. At this time Canadian motivation was focused on restoring its prestige rather than improving relations with the Soviet Union.

Canadian policy-makers were aware of the damages of Canada's international image which were resulting from not participating in international hockey competitions and earlier from poor results in international events. The desire to improve the situation resulted in establishing a non-governmental organization Hockey Canada in February 1969, which was closely interrelated with the federal government. Its aim was to manage and develop Canadian national team and the sport in general, but the issues of national team were a priority. The organization has also begun to negotiate the country's return to international ice hockey competition (Macintosh, Hawes, 1994; Macskimming, 1996). The talks were to enable establishing hockey exchanges with the USSR soon. Hockey Canada can there- 
fore be regarded as a tool used by Canada in order to use ice hockey for the sake of public diplomacy. Its aim was to increase the international prestige of the country and foster establishing closer relations with the selected states, in this case communist countries with the Soviet Union at the forefront.

From the time Pierre Trudeau became the Prime Minister in 1968, one of the main objectives of Canada's foreign policy was the rapprochement with the Soviet Union. This was a part of a wider strategy which was to enhance Canada's sovereignty in international relations (Scherer, Duquette, Mason, 2007; Soares 2008; Scherer, Cantelton, 2013). Trudeau believed that as both countries were successful in ice hockey, it was logical to employ this sport in order to bring the two states closer (Soares, 2007). What is more, Soviet society was also enthusiastic about ice hockey, even though the country did not have traditions in this sport (Guoqi, 2008), especially in comparison to Canada. As a result, the sport seemed to be suited for the diplomatic objectives of the exchanges as they were awaking considerable interests among both societies. The Soviet Union was also positive about Canada's efforts to redefine the mutual relations, which was perceived as a possible way to settle relations with Western states on more predictable basis (Rudd, 2009).

In respect to his strategic objectives, Prime Minister of Canada Pierre Trudeau visited the Soviet Union in 1971 and met with Soviet Prime Minister Alexei Kosygin. The visit was regarded as very successful concerning the state of CanadianSoviet relations. It resulted in signing of the Canadian-Soviet Protocol on Consultations and an umbrella agreement on economic co-operation. Shortly after, Prime Minister Kosygin was invited by his counterpart to visit Canada (Macintosh, Hawes, 1994). The Protocol that has been signed seemed to be particularly significant though. Canadian authorities assessed it as a logical development of the process of diversification of Canada's foreign relations, which was understood as reducing the dependence from the United States and a will to better the relations with communist states of Eastern Europe (Soares, 2014). In the Soviet Union this was perceived as a chance to a partial relaxation of the Western alliance, although this was not the only aim of Canada's government, whose main motivation was improving its own position in international relations.

\section{Hockey Series}

The development of diplomatic contacts between the Soviet Union and Canada encompassed the issue of ice hockey relations as well. Both sides agreed that sport formed a common bond between both countries, which could be used in order 
to strengthen their relations (Macintosh, Hawes, 1994). The whole concept of organizing a hockey exchange series was according to Roy Macskimming (1996) initiated by an article in Soviet newspaper Izvestia, in which it was mentioned that constant Soviet victories in ice hockey at the world championships and at the Olympics were boring and there was a need for new challenges. Canadian diplomats in Moscow considered it a suggestion and soon a meeting between the author of the article Boris Fedosov and employees of Canadian embassy in Moscow Gary Smith and Peter Hancock was arranged. During the meeting the Soviet side expressed a readiness to organize a series of matches between against Canadians playing in NHL. Earlier there was no permission for such an exchange. Apparently both sides were aware of the potential benefits of establishing friendly exchanges in ice hockey, both in terms of international image and political rapprochement. The further developments were dynamic.

The negotiations concerning the planned hockey series between Canada and the USSR were being held simultaneously with the talks between Canada and the IIHF concerning its return to international competition in this sport. Thanks to Soviet support Canadians managed to come to an agreement with the hockey federation during a meeting in Prague in April 1972. At the same time it was decided to organize a series of eight matches between teams from Canada and the Soviet Union, which were to be held in September that year (Macintosh, Hawes, 1994). Half of them were to be played in different cities in Canada, while the other half in Moscow (Macskimming, 1996). The negotiated conditions of the series, according to observes, gave a certain advantage to the Soviets, as the matches were to be played at the NHL pre-season when players are usually in worse shape. The international rules that were agreed, according to which the games were to played with two instead of three referees, also were believed to give some advantage to the Soviet team (Macskimming, 1996). The agreements concerning the series were suggesting that it can be used by the states in order to show their superiority, what could be used for the purpose of propaganda and potentially ruin the positive diplomatic significance of the series, as especially the Soviet side was trying to negotiate solutions giving its team a certain advantage.

The planned summit series was taken in Canada so seriously that a special unit was created in the Department of External Affairs - International Sports Relations Desk in the Public Affairs Bureau (Potter, 2009). The new organizational unit was responsible for preparation to the series, as well as negotiations and protocol issues (Macintosh, Hawes, 1994). The stress put on the protocol can be interpreted as another proof of how Canada cared about using the sports exchange for the sake of political rapprochement with the Soviet Union. 
Just as planned, the hockey series between the national team of the Soviet Union and a Canadian NHL All-Stars team was held in 1972, in autumn (Soares, 2008). The Soviet squad appeared to be very well prepared. For example, as part of its preparations, in order to reduce the jet lag Soviet players for two weeks have been living according to Canadian time. Contrary, Canadians had some problems with even completing the best squad to Team Canada, as NHL teams did not want to let the players miss the preparations in order to play in the series. As a result, some players like Bobby Hull, Gerrie Cheevers, Derek Sanderson or J.C. Tremblay were not able to join Team Canada (Macskimming, 1996). Despite missing a few of their stars, Canadians were regarded as more likely to win in the hockey exchange as for the first time they were able to play against the Soviet Union with their professional hockey players. The exchange can therefore be regarded as a sort of realization of Canadian postulate concerning international hockey competition, which was rejected by the IIHF what eventually led to Canada's withdrawal. Of course it was a friendly series, but it could still bring benefits to Canada in the context of international prestige.

The first four matches were played in Canada, while the latter four in the Soviet Union. The whole summit series ended with a narrow win of the western American country, which secured its victory in an epic way - in the last seconds of the last match in Moscow. Canadian Paul Henderson scored a winning goal 34 seconds before the end of the game. On the whole, Team Canada won four matches, the Soviet Union won three and there was one draw. The series until today is regarded as one of the most important moments of Canadian sport (Soares, 2008).

Team Canada, on their way back home, played one more exhibition match in Prague against national team of Czechoslovakia, the other great hockey power. The match ended in a draw 3-3 (Team Canada, 1972; Podnieks, 2012). All those matches, apart from their public diplomacy dimension, were also treated as an opportunity to arrange meetings between diplomats and politicians. As Robert Ford, ambassador of Canada in Moscow recalled, those meetings together with the hockey series lead to a rise of the Soviet interest in Canada, thus improving the state of diplomatic relations (Macintosh, Hawes, 1994). It should be noted that positive sports diplomacy between unfriendly states very often encompassed arranging purely diplomatic talks on the occasion of sports contacts, even though such circumstances were not necessarily for such meetings.

As has been mentioned, there were concerns that the 1972 hockey series might be treated by both states as a tool to gain international prestige, regardless the political rapprochement. This actually happened and was exceptionally strong in Canada, but the Soviet Union was also motivated to win, although officially 
its representatives claimed that the matches were friendly only and that Soviet team played in order to learn, not to win (Macskimming, 1996). It should not be a surprise that after the last winning match in Moscow Prime Minister Trudeau sent a telegram, in which he congratulated Canadian players and at the same time mentioning, that during the match "all regular activity was put on hold" (CBC, 1972). Till now the hockey series is regarded as one of the most symbolic and mythical events in the history of Canada (Wechmann, 2007). Although Canada won, actually both sides could benefit from the series in terms of international image. Canadians, by winning, recovered their national prestige and honour, while the Soviet Union amateur national team could be proud to lose only narrowly with a team of All-Star professionals. Soviet officials were also suggesting that their national team was in fact better, while the Canadians compensated it only with aggression and violence on ice (Soares, 2007). Apparently both sides were treating the exchange as a matter of national prestige, but at the same time such rhetoric remained low-profile.

Although both states were trying to use the 1972 hockey series for the sake of national prestige and were striving to win it, it should not be forgotten that the most important aim of the exchange was to bring the countries from competitive geopolitical blocks closer. Diplomatic significance of the series was strongly emphasized by both sides, not only by the Canadians. One of the Soviet diplomats was reported to have said, that "with Canada we are looking to a mutual design of friendship through hockey" (Scherer, Duquette, Mason, 2007, p. 172-173). The series was also meant to influence both societies according to the assumption that more people are interested in sport than in international relations (Scherer, Cantelon, 2013). Such attitude is typical for public diplomacy, a category that includes sports diplomacy.

Apart from the aspects of positive sports diplomacy which at this time were apparently dominating in the hockey series, there were also some obstacles. Apart from the issue of the desire to win for the sake of prestige, it was the aggressive style presented by Canadian players. Numerous fouls were leading to a situation that sometimes matches instead of friendship were evoking hostility towards Canadians. For example one of the Canadians have made a throat-slitting gestures at his rivals, while another was to intentionally break one of the Soviet player's ankle after he was instructed to do so from the assistant coach. Of course the Soviets were not totally blameless and were fouling as well (Soares, 2008), but it were the Canadians who were remembered as particularly violent.

The style of play in NHL was generally more aggressive than in international amateur events, but the level of violence was even greater during the 1972 series, 
probably due to the pressure that was being put on the players, as they were expected to "uphold both national honor and professional credibility". Moreover, the players themselves were treating the matches in an emotional way - one of them was reported to have said that the matches symbolized a war between "our way of life against the communist way of life" (Soares, 2007, p. 214). As Canadian Rod Gilbert has said, "we couldn't lose this series. It was the most incredible pressure I've ever been under" (Kreiser, 2012). All those quotes show that despite positive diplomatic aim of the hockey exchange, directed at political rapprochement between the Soviet Union and Canada, the Cold War dichotomy was very clear, especially in the attitudes of the players and in the fact that both states were trying to use the series for the sake of international prestige.

The government of Canada seemed to be aware of the potential threats to the diplomatic dimension of the series. In order to avoid the negative consequences of players' violence and the desire to win, a stress was being put on the ceremonial aspect of the exchange (Wechmann, 2007). This was one of the aims of creating the mentioned International Sports Relations Desk. In general, the 1972 hockey series was assessed ambiguously, but authors seem to agree that the benefits for Canada were dominant. The general policy of Prime Minister Trudeau gave the country greater appreciation in the Soviet Union and made the state more visible (Wechamnn, 2007). The summit series was probably one of the factors that enabled it.

\section{Continuation of Canada - USSR Hockey Diplomacy}

Researches analyzing Canadian-Soviet hockey diplomacy tend to focus on the 1972 summit series that has been presented above. Nevertheless, exchanges in ice hockey were continued in the aftermath. Taking into consideration their diplomatic objectives - bringing the two states closer, they should also be put to the category of hockey diplomacy and therefore should be at least mentioned. The second hockey series was organized two years after the previous one. However, the prestige that was associated with it seemed to be smaller, similarly to the diplomatic significance.

In 1974 a new North American professional ice hockey league World Hockey Association (WHA), which was meant to be a competition to famous NHL, organized a series of matches between Canadians playing in the league and the national team from the Soviet Union. The format of the series was similar to the one in 1972 - four matches in different cities in Canada and four matches in Moscow. The agreement regarding the series was signed during the IIHF congress in 
Helsinki, in March 1974. Although Canadian government was aware of the lower profile of the projected series, its main objective was similar as before - enhancing the bilateral relations, although there were also voices that WHA's aim was also to improve its status (Soares, 2014; Scherer, Cantelon, 2013). The series ended with a Soviet victory - four matches were won by the USSR, there were three draws and the WHA team won one match. This was a surprise, as despite lower prestige than NHL, there were also very good players in the WHA team, who took part also in the 1972 series (Soares, 2014, 2007).

According to John Soares (2014), the 1974 series fit to Pierre Trudeau's aims to improve relations with the Soviet Union and reduce Cold War tensions, while Canada's Ministry of External Affairs considered the series as "obviously important" (p. 2) to the relations between the two states and "extraordinary opportunity to project Canada's image in the USSR of which we should take full advantage" (p. 2). The statements confirm the assumption that the 1974 series, although less known, should also be regarded from the perspective of sports diplomacy.

Organization of the series was not easy despite official political will. Certain IIHF officials for various reasons were opposing it, there were also problems with settlements concerning travels, while violence between players was leading to official diplomatic interventions. Some of the controversies were so serious that there was a risk of aborting the series, for example after Canadian team chartered a plane instead of using public airlines for traveling between cities in Canada, as was negotiated before the series. On the other hand, Canadian officials boycotted one of the matches in Moscow as a consequence of dissatisfaction of the seats that were granted to them. In the report by the Canadian embassy in Moscow it was even stated that provided that the 1972 series probably improved the relations with the Soviet Union, it is very hard to be definite in assessing the diplomatic meaning of the second series (Soares, 2014). As can be seen, although the problems of the 1974 series were similar to those two years before, their influence on the diplomatic impact of the hockey diplomacy appeared to be greater.

The hockey series in 1972 and 1974 between amateurs from the USSR and professionals from Canada are the best known acts of hockey diplomacy, but there were also other exchanges in ice hockey that deserve to be noted. For example, in winter 1975-1976 two Soviet hockey teams CSKA Moscow and Soviet Wings traveled to North America in order to play exhibition matches against American and Canadian teams. During one of such games the best Soviet team, national champions CSKA Moscow played against Montreal Canadiens, a team that won the Stanley Cup four consecutive times between 1976 and 1979. The match, played in Montreal Forum, ended in a draw 3-3. The game was assessed as one of 
the finest hockey games ever played (IIHF, 1975). Then, in 1976, Canada hosted the first of a whole series of Canada Cup tournaments, in which national teams from the Soviet Union and Czechoslovakia, as well as teams of professionals from the USA and Canada (occasionally also from Sweden) competed. In turn, in February 1979, another series Challenge Cup was established, which encompassed three matches between the NHL All-Stars and Soviet national team. After the first two games there was a draw, but the final match was won by Soviets 6-0. The result was perceived by some Canadians as the "loss for democracy" (Soares, 2008, 82; Soares, 2007, 221), albeit it was a match between the Soviet Union and a joined American-Canadian team. Those hockey exchanges also could be considered as elements of a wider Soviet-Canadian hockey diplomacy. Hockey exchanges were continued then, but it appears that their positive diplomatic significance was decreasing and never reached the level of the 1972 series, although most certainly the simple fact of maintaining sports contacts must have affected the mutual perception of the two societies.

\section{Conclusions}

Canadian-Soviet hockey diplomacy, and its narrow perspective that encompass the 1972 summit series in particular, are usually assessed to have revealed the great potential of sports diplomacy, while sport began to be perceived as a innovative diplomatic tool, especially in Canada (Laverty, 2010). This statement appears to be a little exaggerated as for example the most famous act of sports diplomacy - the ping-pong diplomacy between the USA and China was held earlier. Nevertheless, it was the first such act in Canada, a country that is now famous for its welldeveloped sports diplomacy. What is more, sports exchange was not a prerequisite of the further diplomatic contacts between the Soviet Union and Canada, as it was negotiated on the intergovernmental level.

According to Xu Guoqi (2008), the success of Trudeau's hockey diplomacy convinced him to make use of sport also in contacts with other states, for example with China - in the connection with the Summer Olympics in Montreal in 1976. In this respect it should be considered whether hockey diplomacy should in fact be assessed as a success, concerning that there were also some aspects that undermined the positive diplomatic effects of the exchanges. As it appears, regardless all the controversies, particularly concerning the violence between players, Canada USSR hockey diplomacy should be evaluated positively. Canada managed to find its place in Soviet concepts concerning international relations and, most of all, 
became more visible in Soviet society. From this point of view, hockey exchanges have fulfilled their role.

The investigation of hockey exchanges between the Soviet Union and Canada allowed to confirm the hypothesis stating that hockey diplomacy between the two states was in fact a fusion of positive and negative sports diplomacy. Accordingly to all the political objectives, exchanges in ice hockey were obviously aimed at political rapprochement between both countries and there is no doubt about that. However, both sides apart from political cooperation were struggling to win for the sake of prestige. The desire to win on one side is connected to the branding role of sports diplomacy, but this case appeared to go beyond simple nation-branding. As a matter of fact, hockey victories were also regarded from the political perspective, which could be seen for example in speeches of the players or in their violent behavior on ice. There were also clashes concerning the organizational issues. Concerning those contexts, hockey exchanges were encompassing elements of negative sports diplomacy as well, even though they were probably less significant than the positive ones.

Another of the hypotheses that was tested stated that hockey exchange was at the same time an effect and a tool of Canada's and Soviet Union's desire to better their bilateral relations. As has been noted, Canada had been proposing hockey exchanges for a while before it was finally realized. Only after détente in East West relations flourished and when Pierre Trudeau became the Prime Minister of Canada the exchange became possible. To that extent the hockey diplomacy was an effect of better bilateral relations. On the other hand, the hockey exchanges were directly aimed at bringing the states even closer. Bearing this in mind, the hypothesis has been confirmed as well.

According to the last hypothesis, hockey was a well-chosen sport for the sake of sports diplomacy. This hypothesis has been confirmed only partly. The sport was globally associated with Canada, so it was a natural medium for its public diplomacy. The sport was also popular in both societies and as a result the exchanges were receiving a great deal of attention. From this perspective the choice of the sport was good. On the other hand, contacts in such sport were risky as both sides might have wanted to use them for the sake of national prestige, which actually happened. Losses were evoking negative feelings, which were amplified by violence on ice. This was particularly strong in Canada, where ice hockey is regarded as a national sport. Those risks were partly reduced by the fact that the matches were played by Soviet amateur national team and Canadian professional All-Stars teams or simply by teams from professional leagues. The exchanges were therefore encompassing duels between teams that could not meet in the official competi- 
tion, giving the loser a credible justification for his loss. Concluding, the choice of ice hockey was good, but not perfect.

Investigation of hockey diplomacy between Canada and the Soviet Union allowed to make a few observations. Firstly, all the major exchanges were arranged directly by non-governmental subjects. This is typical for public diplomacy and at the same time it is useful when relations between two states are sensitive. Employing such actors reduces the governments' risk of losing prestige if the initiative fails. At the same time, all the exchanges were negotiated on an intergovernmental level - Canada even created a special organizational unit responsible for the hockey exchanges. This proves that the exchanges despite a grass-root character were embodying inter-state diplomacy.

Another observation that has been made refers to the motivation of the $\mathrm{Ca}-$ nadian side. Establishing sports exchanges with the Soviet Union were directly aimed at political rapprochement with this Cold War superpower, but there have also been deeper motivations. First of all, Canada under Pierre Trudeau was searching for a stronger position in international environment. Closer ties with the USSR were seen as a chance to receive greater independence internationally. The other motivation of Canada was to gain national and international prestige, which suffered from losses in international hockey and eventual withdrawal from IIHF. Hockey exchanges with the Soviet Union gave Canada a chance to fulfill both of these goals.

\section{References:}

CBC. (1972). Trudeau Sends Telegram to Canadians after Summit Series. Derived from: http://www.cbc.ca/archives/entry/canada-soviet-series-trudeaus-telegram.

Fulbright Canada. Fulbright Research Helps Moscow Hockey Talk. Derived from: http:// www.fulbright.ca/news/122/15/Fulbright-Research-Helps-Moscow-Hockey-Talk. html.

Godlewski, P. (2009). Problem amatorstwa państwowego w sporcie w okresie PRL. In: J. Chełmecki (eds.), Społeczno-edukacyjne oblicza wspótczesnego sportu i olimpizmu. Sprawność fizyczna dzieci i młodzieży. Warszawa: AWF, 234-246.

Guoqi, X. (2008). Olympic Dream. China and Sports 1895-2008. Cambridge: Harvard University Press.

IIHF. (1975). Montreal and CSKA Play an Epic 3-3 Game on New Year's Eve. Derived from: http://www.iihf.com/iihf-home/the-iihf/100-year-anniversary/100-top-stories/ story-23/.

Kreiser, J. (2012). 1972 Summit Series Shaped Modern Hockey. Derived from: http://www. nhl.com/ice/news.htm?id=640724. 
Laverty, A. (2010). Sports Diplomacy and Apartheid South Africa. Derived from: http:// theafricanfile.com/politicshistory/sports-diplomacy-and-apartheid-south-africa/.

Macintosh, D., Hawes, M. (1994). Sport and Canadian Diplomacy. Montreal: McGillQueen's University Press.

Macskimming, R. (1996). Cold War. The Amazing Canada-Soviet Hockey Series of 1972. Vancouver: Heritage House Publishing Co.

Ociepka, B. (2013). Miękka sita i dyplomacja publiczna Polski. Warszawa: Scholar.

Pamment, J. (2013). New Public Diplomacy in the 21st Century. A Comparative Study of Policy and Practice. Abingdon: Routledge.

Podnieks, A. (2012). Team Canada 1972: The Official 40th Anniversary Celebration of the Summit Series. Toronto: FENN-M\&S.

Potter, E.H. (2009). Branding Canada: Projecting Canada's Soft Power through Public Diplomacy. Montreal: McGill-Queen's University Press.

Rowe, D. (2011). Global Media Sport. Flows, Forms and Futures. London: Bloomsbury.

Rudd, C.A. (2009). The Constant Diplomat: Robert Ford in Moscow. Montreal: McGillQueen's University Press.

Saxena, A. (2011). The Sociology of Sport and Physical Education. New Delhi: Sports Publications.

Scherer, J., Cantelon, H. (2013). The Forgotten Series: 1974 WHA All-Stars vs. the Soviet National Team: Franchise Recognition, Ageing Icons and Foreign Diplomacy. Journal of Canadian Studies, Vol. 47, Issue 2, 321-363.

Scherer, J., Duquette, G.H., Mason, D.S. (2007). The Cold War and the (Re)articulation of Canadian National Identity: the 1972 Canada-USSR Summit Series, In: S. Wagg, D.L. Andrews (eds.), East Plays West. Sport and the Cold War. Abingdon: Routledge, 163-186.

Soares, J. (2007). Cold War, Hot Ice: International Ice Hockey 1947-1980. Journal of Sport History, Vol. 34, no. 2, 207-230.

Soares, J. (2008). The Cold War on Ice. Brown Journal of World Affairs, Vol. XIV, Issue 2, 77-87.

Soares, J. (2014). "Difficult to Draw a Balance Sheet": Ottawa Views at the 1974 CanadaUSSR Hockey Series. Washington: CWIHP.

Team Canada 1972. Derived from: http://teamcanada1972.ca/summitseries.

Wechmann, J. (2007). The Great Canadian Myth Exposed: The 1972 Summit Series in Diplomatic and Domestic Perspective. In: C. Bates, G. Huggan, M. Marinkova, J. Orr (eds.), Visions of Canada, Vol. 6, 1-18. Brno: The Central European Association for Canadian Studies. 